\title{
Early establishment of Douglas-fir and ponderosa pine in grassland seedbeds
}

\author{
YUGUANG BAI, DON THOMPSON, AND KLAAS BROERSMA
}

Authors are range ecologist, range plant physiologist, and soil scientist, Kamloops Range Research Unit, Agriculture and Agri-Food Canada, Kamloops, BC V2B 8 A9 Canada. Funding for this research was provided by Beef Cattle Industry Development Fund, Matching Investment Initiative Fund, and Natural Science and Engineering Research Council (Canada).

Abstract

Grasslands of interior British Columbia are being encroached upon by Douglas-fir (Pseudotsuga menziesii var. glauca (Beissn.) Franco) and ponderosa pine (Pinus ponderosa Dougl.). A pot experiment placed in the field was conducted to determine the effect of forest and grassland seedbeds on seedling emergence and early establishment of the 2 species with 2 seed collections each. For these seedbeds, structural characteristics were evaluated and the effect of seedbeds water extracts on seed germination was determined. Seedling emergence of both species was significantly reduced by Douglas-fir needles and enhanced by fescue litter and cattle manure compared to mineral soil. The rate of emergence was reduced by Douglas-fir needles and sagebrush litter, and for some collections, by ponderosa pine needles, but was always enhanced by manure compared to mineral soil. Seedling survival was generally not affected by seedbeds. Douglas-fir seedlings emerging earlier in the season survived better, and both Douglas-fir and ponderosa pine seedlings emerging earlier lived longer than these emerging later. Seed germination of ponderosa pine was not affected by the water extract while that of Douglasfir was reduced by the water extract from sagebrush litter. Therefore, differences in seedling emergence of the 2 species among seedbeds were related more to structural than to chemical characteristics of seedbeds. Successful establishment of the 2 species in grasslands within this region likely relies on the ability of seeds to germinate early in the growing season on seedbeds in which soil moisture is conserved, as summer droughts are severe.

Key Word: allelopathy, litter structure, seedbed ecology, Pinus ponderosa Dougl., Pseudotsuga menziesii var. glauca (Beissn.) Franco

The encroachment of woody plants is a major threat to range resources at a global scale, reducing grassland area and carrying capacity, and inhibiting livestock movement (Burkhardt and Tisdale 1976, Strang and Parminter 1980, Gruell 1983, MacDonald and Wissel 1991, Richardson and Bond 1991). Fire

The authors wish to thank Dr. Walter Majak for advice on the water extract experiment, Ms. Barbara Brooke and Christine Kelly for technical assistance, and Drs. J.T. Romo and Walter Willms for reviewing this manuscript.

Manuscript accepted 1 Jan. 2000.

\section{Resumen}

Los pastizales del interior de Columbia Británica están siendo invadidos por "Douglas-fir" (Pseudotsuga menziesii var. Glauca (Beissn.) Franco) y "Ponderosa Pine"(Pinus ponderosa Dougl.). Se realizó un experimento en macetas, ubicado en el campo, con el objetivo de determinar el efecto de la cama de siembra (bosque y pastizal) y el origen de la semilla (dos colecciones) en la emergencia y establecimiento de plántulas de estas especies arbóreas. Se evaluaron las características estructurales de la cama de siembra y extractos de agua de ellas en la germinación de la semilla. Las hojas de "Douglas-fir" redujeron significativamente la emergencia de plántulas de ambas especies, en cambio en el mantillo de "fescue" y el estiércol de ganado la aumentaron, esto en comparación con el suelo mineral. La tasa de emergencia se redujo por las hojas de ADouglas-fir" y el mantillo de "Sagebrush"; en algunas colecciones de semilla las hojas de "Ponderosa pine" también redujeron la tasa de emergencia, sin embargo, la tasa de emergencia siempre mejoró con el estiércol comparado con el suelo mineral. En general, las camas de siembra no afectaron la sobrevivencia de las plántulas. Las plántulas de "Douglas-fir" emergieron mas temprano y sobrevivieron mejor, las plántulas que emergieron primero, tanto de "Douglasfir" como de "Ponderosa pine", vivieron mas tiempo que las que nacieron al último. La germinación de semillas de "Ponderosa pine" no fue afectada por el extracto de agua mientras que la de semillas "Douglas-fir" si se redujo con el extracto de agua de mantillo de "Sagebrush". Por lo tanto, la diferencia en germinación de plántulas de las dos especies se relaciono mas a las características estructurales que a las características químicas de la cama de siembra. El establecimiento exitoso de las dos especies en los pastizales de esta región, se basa, probablemente, en la capacidad de las semilla para germinar a inicios de la estación de crecimiento en camas de siembra en las que la humedad del suelo se conserva en el verano cuando la sequía es severa.

suppression, disturbance, climatic variation, and interactions of these factors in the last 100 to 150 years are thought to be responsible for tree encroachment (Tisdale 1950, Parminter 1978, Strang and Parminter 1980, Arno and Gruell 1986, Mast et al. 1998). In the southern interior of British Columbia, conifer forests are the dominant vegetation; natural grasslands are limited resources and are susceptible to tree encroachment. Tree encroachment was first reported about 80 years ago (Whitford and Craig 1918) and the loss of grasslands to encroachment in recent years was more than $30 \%$ over a 30 -year period in certain areas (Ross 1997). 
The dominant conifer species in the grassland/forest ecotone, interior Douglasfir (Pseudotsuga menziesii var. glauca (Beissn.) Franco) and ponderosa pine (Pinus ponderosa Dougl.), regenerate from seeds. The invasion by trees requires a sequence of favorable events from seed production and dispersal to seedling emergence and survival (Hill et al. 1995). Therefore, understanding the eco-physiological aspects of seed germination, seedling emergence, and seedling establishment of these tree species under grassland conditions is critical in explaining this phenomenon, and in providing a baseline for management strategies aimed at controlling tree encroachment. Numerous researchers have studied the effects of forest floors on seedling emergence and establishment of conifers (Bramble and Goddard 1942, Chrosciewicz 1974, Williams et al. 1990, McLaren and Janke 1996). Douglas-fir litter inhibited seedling emergence of itself in a monocultural plantation by reducing water availability and by acting as a mechanical barrier (Caccia and Ballaré 1998). Seedling emergence of ponderosa pine was generally enhanced by mineral or ash covered soils compared to undisturbed soils covered with plant litter (Roe and Squillance 1950, Foiles and Curtis 1965). No study has compared seedling establishment of conifers, particularly Douglas-fir and ponderosa in forest and grassland seedbeds. Objectives of this study were to determine: (1) effects of mineral soil, litter of grass and big sagebrush (Artemisia triden tata Nutt. ssp. wyomingensis Beetle \& Young), needles of Douglas-fir and ponderosa pine, and cattle manure on seedling emergence and establishment of Douglasfir and ponderosa pine, and (2) if significant differences were found in seedling emergence and establishment among seedbeds, whether they were attributed to structural or chemical characteristics of these materials.

\section{Materials and Methods}

\section{Seed collection and treatment}

Two collections of Douglas-fir and 2 collections of ponderosa pine seeds were obtained from British Columbia Ministry of Forests Tree Seed Centre and were stored at $-18^{\circ} \mathrm{C}$ before use (Table 1). These seeds were collected from low elevation sites $(<1,000 \mathrm{~m}$ above sea level) in the grassland/forest ecotone, within $50 \mathrm{~km}$ from Kamloops.

In the seedbed experiment, seeds were

Table 1. Descriptions of Douglas-fir and ponderosa pine seed collections from the Interior of British Columbia.

\begin{tabular}{llccc}
\hline \hline Species/collection & \multicolumn{1}{c}{ Location } & Elevation & Date & Seed \\
\hline & & $(\mathrm{m})$ & & $\left(\mathrm{No.g}^{-1}\right)$ \\
Douglas-fir 1 & Nesbitt Lake, 50 $40^{\circ} \mathrm{N} 121^{\circ} 06^{\prime} \mathrm{W}$ & 900 & Sep. 93 & 75 \\
Douglas-fir 2 & Pher Lane, 50 $43^{\circ} \mathrm{N} 120^{\circ} 52^{\prime} \mathrm{W}$ & 750 & Aug. 93 & 80 \\
Ponderosa pine 1 & Sugarloaf Hill, 50 $30^{\circ} \mathrm{N} 120^{\circ} 27^{\prime} \mathrm{W}$ & 875 & Aug. 94 & 19 \\
Ponderosa pine 2 & Indian Gardens, 50 $50^{\circ} 44^{\prime} \mathrm{N} 120^{\circ} 49^{\prime} \mathrm{W}$ & 725 & Aug. 95 & 21 \\
\hline
\end{tabular}

subjected to field stratification. Seeds were soaked in pre-cooled distilled water at $4^{\circ} \mathrm{C}$ for 2 hours and then placed in the field in early December 1997. The field site was located within a long-term exclosure dominated by rough fescue (Festuca campestris Rydb.) within the Lac du Bois Grasslands near Kamloops at an elevation of $900 \mathrm{~m}$. Approximately 60 seeds were placed in each custom made, metal screen envelope $(6 \times 8 \mathrm{~cm})$. These envelopes were randomly placed at the bottom of each of the 4 metal screen boxes $(60 \times 60$ $x 5 \mathrm{~cm}$ ). These boxes were fixed to the ground with their bottoms $1 \mathrm{~cm}$ below the soil surface and covered with grass litter. The lids of boxes were then sealed with metal wire to minimize seed predation and covered with grass litter. Seeds were retrieved from the field on 1 May 1998. Seeds used in the water extract experiment were not stratified.

\section{Seedbed experiment}

Seedbed experiment was conducted in a randomized complete block design with 6 treatments, including mineral soil, Douglas-fir needle, ponderosa pine needle, sagebrush litter, fescue litter and cattle manure. This was a pot experiment placed in the field with 4 replicates and the experiment was repeated. Mineral soil from the top $15 \mathrm{~cm}$ of the soil profile was collected along a roadside in the Lac du Bois Grasslands. The soil was then sifted through a $1.0 \mathrm{~cm}$ sieve and heated at $80^{\circ} \mathrm{C}$ for 48 hours to eliminate viable seeds. Other litter materials, including needles of Douglas-fir and ponderosa pine from ground, dry leaves of big sagebrush from standing plants, standing dead leaves of rough fescue, and dry cattle manure more than 1-year old, were collected from the Lac du Bois Grasslands. Douglas-fir needles were separated from twigs, cones, and rocks with a $3.5 \mathrm{~mm}$ sieve and then sorted on a $2.0 \mathrm{~mm}$ sieve to remove seeds and other small objects. Ponderosa pine needles and the rough fescue litter were hand sorted and cut to fit into pots. Cattle manure was broken into fragments of about $1 \mathrm{~cm}$ in diameter.
Pots measuring $12 \times 12 \times 12 \mathrm{~cm}$ were filled with $8 \mathrm{~cm}$ of mineral soil and covered with seedbed materials. The litter depths selected were similar to those observed in the field, $1 \mathrm{~cm}$ depth for big sagebrush litter and $3 \mathrm{~cm}$ for Douglas-fir and ponderosa pine needles, fescue litter and cattle manure. Mineral soil treatment was not covered by any litter. Forty seeds were placed on the litter surface in each pot and shaken by hand. Seeds in the mineral soil treatment remained visible on the surface; those in fescue litter and ponderosa pine needle treatments fell to the bottom of the seedbed materials within 1 $\mathrm{cm}$ from mineral soils. Seeds in the Douglas-fir needle, sagebrush litter and cattle manure treatments remained at the top $0.5 \mathrm{~cm}$ of the seedbed materials but invisible from the surface. Pots were then placed outside under tree canopies and covered with mesh metal screens to minimize seed predation by birds and other animals. The first trial was initiated on 12 May 1998 and the second trial 2 weeks later. The duration of each trial was 90 days. Air temperatures during the experimental period were obtained from the weather station at Kamloops Airport, which is located about $1 \mathrm{~km}$ south of the experimental site.

Four hundred $\mathrm{ml}$ of distilled water were applied to each pot at the beginning of the experiment to ensure that the soil reached field capacity. Four additional pots filled with mineral soil were used as controls to monitor soil water change and to ensure no seeds survived the oven-drying process. Control pots were weighed every 2 days before watering for soil water content determination. One hundred $\mathrm{ml}$ of distilled water were added to each pot of the experiment on each of the first 3 checking dates. Fifty $\mathrm{ml}$ of distilled water were added each time when the soil moisture content in the control pots was below $35 \%$ d.w., a pre-determined level about $80 \%$ of the soil field capacity. Seedling emergence was checked every 2 days. Seedlings that reached at least $1 \mathrm{~cm}$ above the soil surface (mineral soil treatment) or $3 \mathrm{~mm}$ above litter materials (all other treatments) were considered emerged. Day of emer- 
gence for each seedling was recorded and seedlings were marked with colored paper clips. Dead seedlings, determined by visual inspection, were recorded and removed. The total length of each surviving seedling was measured at the end of the experiment; seedlings were washed, oven-dried at $80^{\circ} \mathrm{C}$ for 48 hours, and weighed.

Bulk density of mineral soil and other seedbed materials was determined as dry weight per gross volume after oven drying at $80^{\circ} \mathrm{C}$ for 48 hours. Net volume was estimated by placing materials into beakers filled with a pre-determined amount of distilled water. The increase in the volume of distilled water after adding these materials was determined after 10 seconds. The relative volume of seedbed materials was calculated as the percentage of net volume in gross volume. There were 8 replicates for each seedbed type using different samples from the above seedbed experiment.

\section{Water extract experiment}

The 6 types of seedbed materials used in the above experiment as well as soils from beneath Douglas-fir needle, ponderosa pine needle, big sagebrush litter, fescue litter and cattle manure were used in the water extract experiment. With distilled water being the control, this experiment had 12 treatments arranged in a completely randomized design with 4 replicates and was repeated once. The amount of materials used for water extract was determined on a volume base: $1 \times 12 \times 12 \mathrm{~cm}$ for big sagebrush litter, mineral soil and soils (top $15 \mathrm{~cm}$ ) from beneath Douglas-fir needle, ponderosa pine needle, big sagebrush litter, fescue litter and cattle manure; $3 \times 12$ x $12 \mathrm{~cm}$ for Douglas-fir needle, ponderosa pine needle, fescue litter and cattle manure. These materials were soaked in $400 \mathrm{ml}$ of distilled water, shaken for 30 min, and allowed to sit for 24 hours at room temperature $\left(22 \pm 1^{\circ} \mathrm{C}\right)$. The water extract was obtained by filtering the solution through 1 layer of Whatman No. 1 filter paper then 1 layer of Whatman $0.2 \mu \mathrm{m}$ membrane filter paper. Seeds of 1 Douglas-fir collection and 1 ponderosa pine collection were used in germination tests with 50 seeds in each petri dish $(9.5$ $\mathrm{cm}$ in diameter). Five $\mathrm{ml}$ of water extract were added to seeds on top of 2 layers of Whatman No. 1 filter paper and covered with 1 layer of filter paper to ensure full contact between seeds and water extract. Petri dishes were placed in clear plastic bags and incubated in a germinator at $30 / 20^{\circ} \mathrm{C}$ for 4 weeks, with 16 -hour light/8hour darkness. The top filter paper was removed after 2 days of incubation. A seed was considered germinated when the radicle was $\geq 2 \mathrm{~mm}$ and germination was checked every 2 days. Small amounts of distilled water were added to the filter paper when needed.

\section{Data analysis}

Data for each seed collection were analyzed separately. Seedling emergence rate index (ERI)/seed germination rate index (GRI) were calculated as the summation of percent seedling emergence/seed germination on each checking date divided by days, then multiplied by 100 (Evetts and Burnside 1972). Total seedling mortality was the percentage of dead seedlings over total emerging seedlings. Data of total emergence, mortality, and germination percentage were transformed with arcsine before being subjected to Analysis of Variance (Snedecor and Cochran 1980). A 3-Way Analysis of Variance was used to analyze data of the seedbed experiment (treatment, block and trial) and a 2-Way Analysis of Variance was used for the water extract experiment (treatment and trial). When interactions between treatment and trial were significant $(\mathrm{P} \leq 0.05)$, data were further analyzed within each trial. Means were separated with LSD test. Seedling emergence data were pooled according to species and collections and regression analysis was used to determine relationships between seedling mortality and day of emergence, and between longevity (difference between day of emergence and day of death) and day of emergence. Days in which less than 4 seedlings emerged were excluded from regression analysis for mortality; best-fit equations were selected. Statistical significance for all tests was assumed at $\mathrm{P} \leq 0.05$.

\section{Results}

\section{Effect of seedbed types on seedling emergence}

Percent emergence and seedling emergence rate index (ERI) were significantly affected by seedbed types in both species, ranging from 2.5 to $84.6 \%$, and from 0.06 to $5.15 \%$ day $^{-1}$, respectively (Table 2 ). Compared to mineral soil treatment, emergence from fescue litter and manure was higher, and that from Douglas-fir needle and big sagebrush litter was mostly lower. Percent seedling emergence in the ponderosa pine needle treatment was not significantly different from that in the mineral soil treatment for both species. Mineral soil treatment had lower seedling emergence in trial 2 than trial 1 for ponderosa pine 2 (data not shown), which resulted in a significant interaction between treatment and trial. The mean daily temperature in the first 4 weeks was $1.5^{\circ} \mathrm{C}$ higher for trial 2 than 1 , and the soil water content in the control pots was $2.4 \%$ lower between weeks 2 and 4 for trial 2 than 1 (data not shown).

Seedling emergence rate, measured by ERI, was significantly higher in manure treatment and lower in Douglas-fir needle and big sagebrush litter treatments than in the mineral soil treatment (Table 2). The emergence rate index (ERI) did not significantly differ between mineral soil and fescue litter treatments, but was similar or lower in ponderosa pine needle compared to mineral soil treatment. The interaction between treatment and trial was significant for Douglas-fir 1 and ponderosa pine 2, apparently caused by the lower ERI for the mineral soil treatment in trial 2.

\section{Seedling mortality and longevity as affected by seedbed type}

Total seedling mortality over the experimental period ranged from 30 to $88 \%$ of total emerging seedlings, but was generally not affected by seedbed type (Table 2). Only in Douglas-fir 2 was seedling mortality significantly higher in the Douglasfir needle treatment than others. Longevity of seedlings which did not survive to the end of the experiment was highest in mineral soil, manure and fescue litter, lowest in Douglas-fir needle, and intermediate in ponderosa pine needle and sagebrush litter in 3 of the 4 collections. Seedling longevity of ponderosa pine 2 was not affected by seedbed type.

\section{Seedling length and weight as affected by seedbed type}

The length of seedlings that survived to the end of experiments was significantly affected by seedbed type for Douglas-fir, but not ponderosa pine (Table 2). Seedlings were longest in mineral soil and manure, shortest in sagebrush litter, and intermediate in Douglas-fir needle, ponderosa pine needle, and fescue litter. Seedling dry weight was greatest in mineral soil and manure, lowest in Douglas-fir needle, and intermediate in others in all seed collections except for ponderosa pine 1 , in which seedling weight was not affected by seedbed type.

\section{Relation between seedling mortality, longevity, and day of emergence}

Pooling seedling mortality data according to day of emergence showed that 
Table 2. Percent of seedling emergence, emergence rate index (ERI), mortality, longevity, and the length and weight of Douglas-fir and ponderosa pine seedlings as affected by seedbed type.

\begin{tabular}{|c|c|c|c|c|c|c|}
\hline $\begin{array}{l}\text { Species/Seedbed } \\
\text { collection }\end{array}$ & Emergence & ERI & Mortality & Longevity & Length & Weight \\
\hline & $(\%)$ & $\left(\%\right.$ day $\left.^{-1}\right)$ & $(\%)$ & (day) & $(\mathrm{cm})$ & $\left(\mathrm{mg} \mathrm{seedling}^{-1}\right)$ \\
\hline $\begin{array}{l}\text { Douglas-fir } 2 \\
\text { Mineral soil } \\
\text { Douglas-fir } \\
\text { Ponderosa pine } \\
\text { Sagebrush } \\
\text { Fescue } \\
\text { Manure }\end{array}$ & $\begin{array}{r}47.8 \pm 4.1 \mathrm{~b} \\
6.6 \pm 2.1 \mathrm{~d} \\
59.1 \pm 2.6 \mathrm{~b} \\
31.6 \pm 7.0 \mathrm{c} \\
77.2 \pm 2.1 \mathrm{a} \\
84.6 \pm 2.4 \mathrm{a}\end{array}$ & $\begin{array}{l}3.12 \pm 0.29 \mathrm{bc} \\
0.14 \pm 0.04 \mathrm{e} \\
2.42 \pm 0.15 \mathrm{c} \\
1.04 \pm 0.21 \mathrm{~d} \\
3.50 \pm 0.16 \mathrm{~b} \\
5.15 \pm 0.17 \mathrm{a}\end{array}$ & $\begin{array}{l}50.1 \pm 5.6 \mathrm{~b} \\
87.5 \pm 6.6 \mathrm{a} \\
60.0 \pm 5.6 \mathrm{~b} \\
57.8 \pm 10.2 \mathrm{~b} \\
47.6 \pm 3.8 \mathrm{~b} \\
34.7 \pm 5.8 \mathrm{~b}\end{array}$ & $\begin{array}{l}29.4 \pm 3.0 \mathrm{ab} \\
14.0 \pm 3.3 \mathrm{c} \\
24.7 \pm 2.2 \mathrm{~b} \\
16.5 \pm 2.0 \mathrm{c} \\
27.2 \pm 2.3 \mathrm{~b} \\
32.6 \pm 2.0 \mathrm{a}\end{array}$ & $\begin{aligned} 12.4 & \pm 0.8 \mathrm{a} \\
8.6 & \pm 0.4 \mathrm{~cd} \\
10.1 & \pm 0.7 \mathrm{bc} \\
7.9 & \pm 0.9 \mathrm{~d} \\
9.7 & \pm 0.4 \mathrm{~cd} \\
11.8 & \pm 0.6 \mathrm{ab}\end{aligned}$ & $\begin{array}{l}19.0 \pm 1.3 \mathrm{a} \\
12.7 \pm 3.0 \mathrm{~cd} \\
15.8 \pm 0.8 \mathrm{bc} \\
11.4 \pm 2.1 \mathrm{~d} \\
15.9 \pm 0.7 \mathrm{abc} \\
18.8 \pm 0.4 \mathrm{ab}\end{array}$ \\
\hline $\begin{array}{l}\text { Ponderosa pine } 2 \\
\quad \text { Mineral soil } \\
\text { Douglas-fir } \\
\text { Ponderosa pine } \\
\text { Sagebrush } \\
\text { Fescue } \\
\text { Manure }\end{array}$ & $\begin{aligned} 41.1 & \pm 10.0 \mathrm{~cd} \\
3.1 & \pm 0.6 \mathrm{e} \\
49.7 & \pm 3.4 \mathrm{bc} \\
27.8 & \pm 5.1 \mathrm{~d} \\
61.6 & \pm 3.5 \mathrm{~b} \\
82.5 & \pm 4.3 \mathrm{a}\end{aligned}$ & $\begin{array}{l}2.30 \pm 0.42 \mathrm{~b} \\
0.08 \pm 0.02 \mathrm{e} \\
1.48 \pm 0.14 \mathrm{c} \\
0.91 \pm 0.18 \mathrm{~d} \\
2.16 \pm 0.14 \mathrm{~b} \\
3.48 \pm 0.32 \mathrm{a}\end{array}$ & $\begin{array}{l}55.0 \pm 4.6 \mathrm{a} \\
42.9 \pm 17.0 \mathrm{a} \\
30.2 \pm 5.9 \mathrm{a} \\
41.4 \pm 8.7 \mathrm{a} \\
42.9 \pm 7.8 \mathrm{a} \\
53.5 \pm 9.2 \mathrm{a}\end{array}$ & $\begin{array}{l}32.3 \pm 5.5 \mathrm{a} \\
15.7 \pm 1.7 \mathrm{a} \\
18.2 \pm 3.4 \mathrm{a} \\
18.2 \pm 3.9 \mathrm{a} \\
21.7 \pm 1.9 \mathrm{a} \\
25.7 \pm 1.9 \mathrm{a}\end{array}$ & $\begin{array}{l}16.3 \pm 2.0 \mathrm{a} \\
12.6 \pm 2.1 \mathrm{a} \\
13.7 \pm 1.1 \mathrm{a} \\
12.6 \pm 1.2 \mathrm{a} \\
14.6 \pm 1.1 \mathrm{a} \\
13.6 \pm 0.7 \mathrm{a}\end{array}$ & $\begin{array}{l}44.9 \pm 4.2 \mathrm{a} \\
21.2 \pm 2.7 \mathrm{c} \\
34.9 \pm 3.0 \mathrm{~b} \\
36.1 \pm 2.0 \mathrm{~b} \\
38.8 \pm 4.2 \mathrm{ab} \\
38.0 \pm 2.5 \mathrm{ab}\end{array}$ \\
\hline
\end{tabular}

${ }^{1}$ Values are mean \pm SE of 8 replicates and data from 2 trials were pooled. Means with the same letter within a collection and a parameter are not significantly different at $\mathrm{P} \leq 0.05$.

seedling mortality increased by nearly $1 \%$ day $^{-1}$ with time of emergence in Douglasfir, indicating that seedlings emerging early in the season survived better than those emerging later (Fig. 1). Time of emergence had no significant effect on seedling mortality in ponderosa pine as indicated by the low $\mathrm{r}^{2}$ value (although for ponderosa pine 2, $\mathrm{P}$ was less than 0.05 ). Longevity of those seedlings decreased with time of emergence at a rate of approximately 0.5 day $^{-1}$ for both species, indicating that seedlings emerging early in the season lived longer than those emerging later (Fig. 2).

\section{Structural characteristics of seedbed}

Both bulk density and relative volume varied significantly among the 6 seedbed types (Fig. 3). Bulk density decreased in the order from mineral soil, cattle manure, Douglas-fir needle, big sagebrush litter, ponderosa pine needle, to fescue litter. Relative volume decreased in the order of mineral soil, cattle manure, big sagebrush litter, Douglas-fir needle, ponderosa pine needle, and fescue litter, but there was no significant difference between the latter 2 types.
Effect of water extract on seed germination

Germination percentage and germination rate index (GRI) of ponderosa pine seeds were not affected by the 12 water extract treatments, averaging $89.8 \pm 0.4 \%$ and $7.70 \pm 0.17 \%$ day $^{-1}$, respectively (data not shown). The treatment effect was significant for Douglas-fir (Table 3). Compared to distilled water and water extract from mineral soil, water extract

Table 3. Seed germination percentage and germination rate index (GRI) of Douglas-fir as affected by water extract of seedbed materials and of soil beneath them.

\begin{tabular}{lcc}
\hline \hline Water extract & Germination & GRI \\
\hline & $(\%)$ & $\left(\%\right.$ day $\left.^{-1}\right)$ \\
Distilled water & $90.7 \pm 1.7 \mathrm{~b}^{1}$ & $9.69 \pm 0.20 \mathrm{~cd}$ \\
Douglas-fir & $93.3 \pm 1.1 \mathrm{ab}$ & $9.84 \pm 0.22 \mathrm{c}$ \\
Ponderosa pine & $90.5 \pm 1.7 \mathrm{~b}$ & $9.13 \pm 0.33 \mathrm{~d}$ \\
Sagebrush & $69.4 \pm 3.5 \mathrm{c}$ & $7.13 \pm 0.21 \mathrm{e}$ \\
Fescue & $90.3 \pm 1.8 \mathrm{~b}$ & $10.15 \pm 0.27 \mathrm{bc}$ \\
Manure & $93.2 \pm 1.1 \mathrm{ab}$ & $10.74 \pm 0.22 \mathrm{ab}$ \\
Mineral soil & $90.7 \pm 1.8 \mathrm{~b}$ & $11.04 \pm 0.18 \mathrm{a}$ \\
Soil beneath Douglas-fir & $91.8 \pm 1.0 \mathrm{~b}$ & $9.98 \pm 0.28 \mathrm{c}$ \\
Soil beneath ponderosa pine & $95.5 \pm 1.1 \mathrm{a}$ & $10.31 \pm 0.21 \mathrm{bc}$ \\
Soil beneath sagebrush & $89.0 \pm 1.6 \mathrm{~b}$ & $10.35 \pm 0.19 \mathrm{abc}$ \\
Soil beneath fescue & $91.3 \pm 1.6 \mathrm{~b}$ & $9.85 \pm 0.32 \mathrm{c}$ \\
Soil beneath manure & $91.2 \pm 0.9 \mathrm{~b}$ & $10.14 \pm 0.22 \mathrm{bc}$
\end{tabular}

${ }^{\mathrm{T}}$ Values are mean \pm SE of 8 replicates. Means with the same letter within a collection and a parameter are not significantly different at $\mathrm{P} \leq 0.05$. 


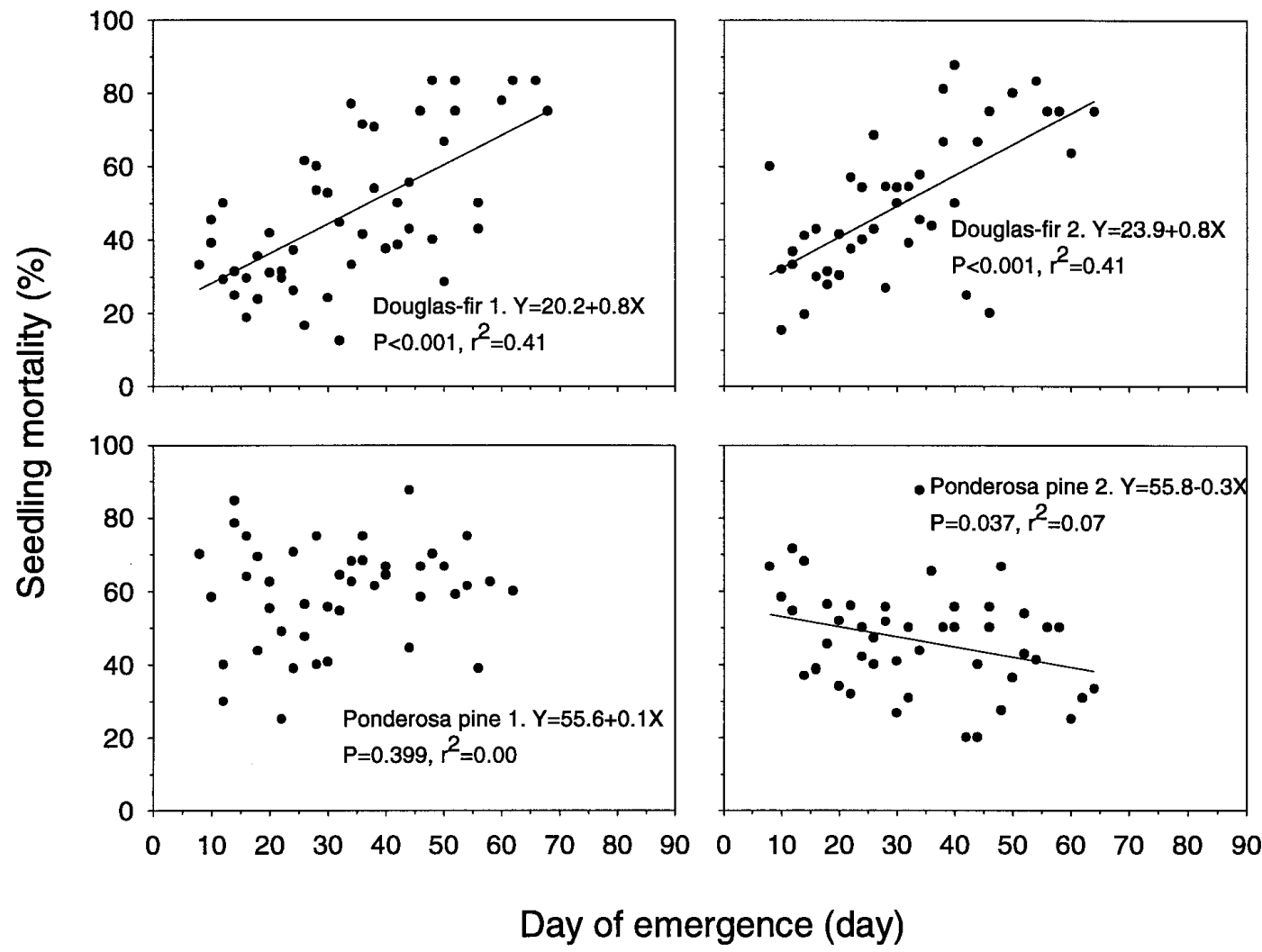

Fig. 1. Seedling mortality of Douglas-fir and ponderosa pine as a function of day of emergence. Data for all treatments were pooled according to species and collection.

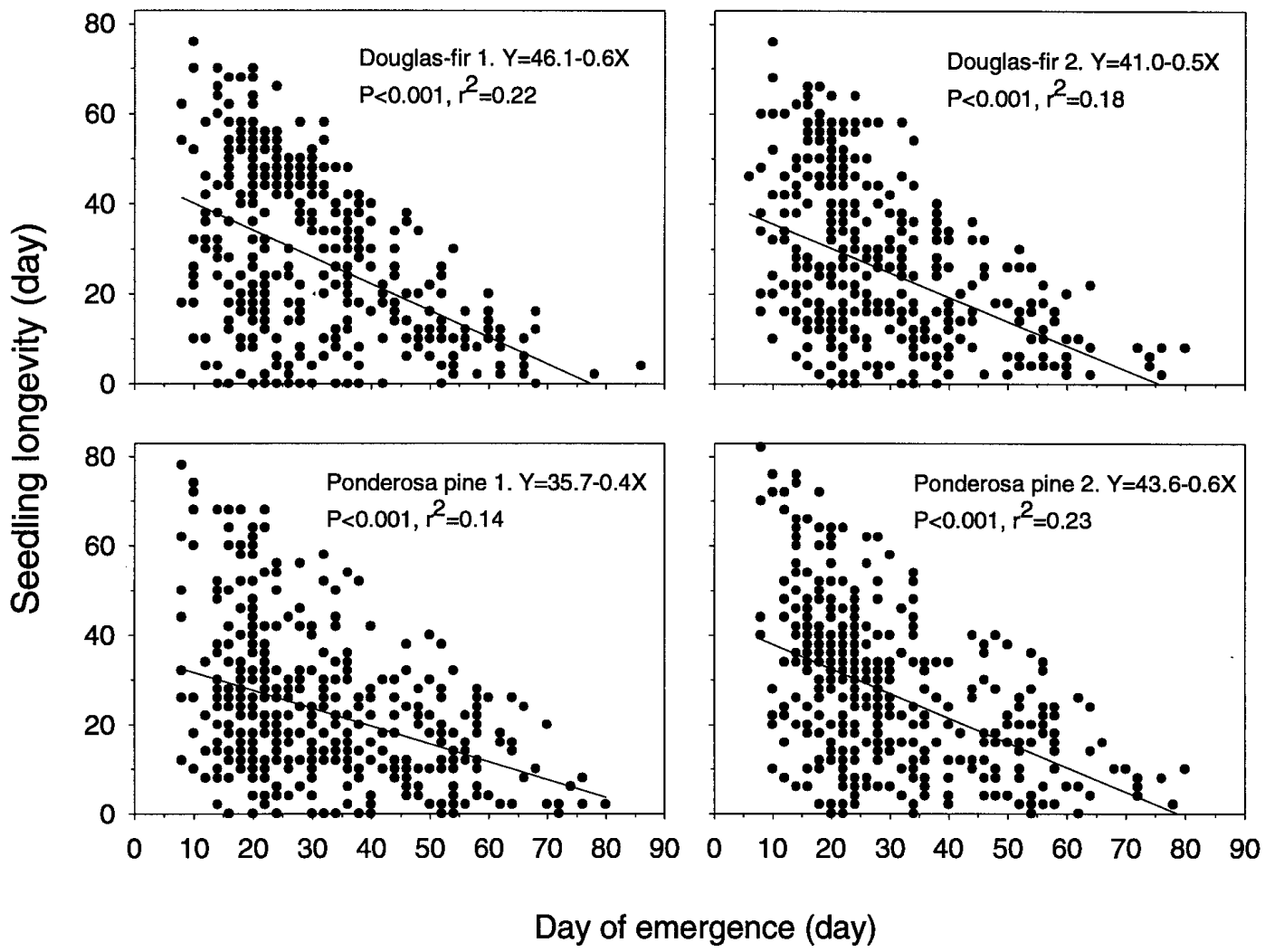

Fig. 2. Seedling longevity of Douglas-fir and ponderosa pine in relation to day of emergence. Data for all treatments were pooled according to species and collection. 


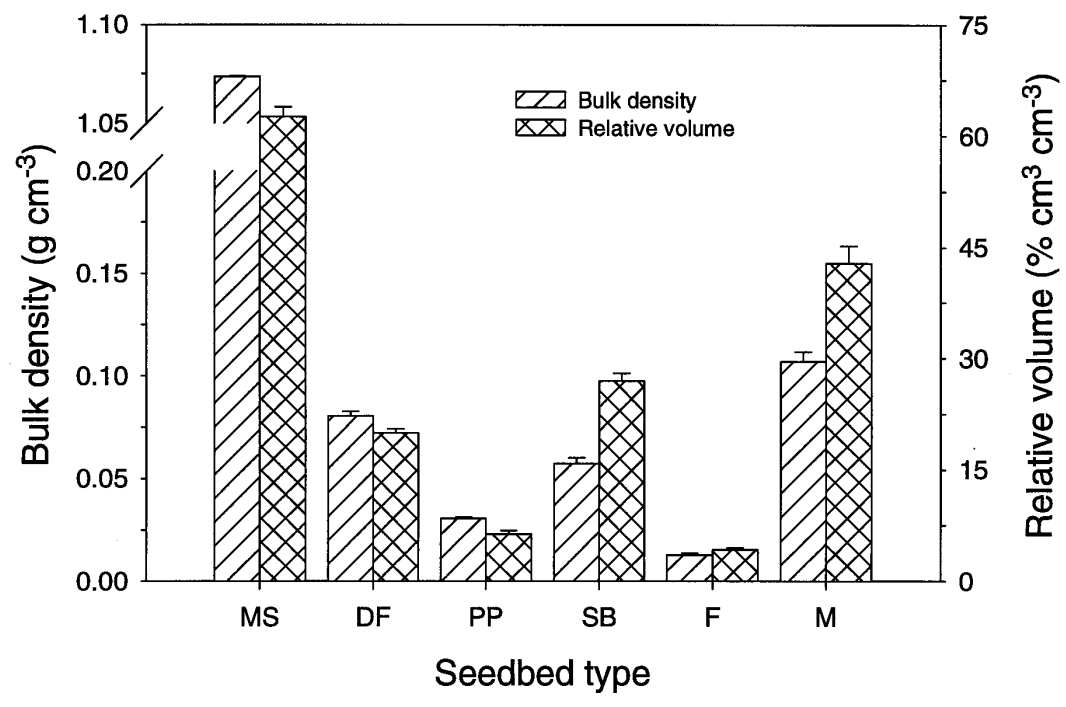

Fig. 3. Structural characteristics of the 6 seedbeds. Data are mean \pm SE of 8 replicates. MS: mineral soil, DF: Douglas-fir needle, PP: ponderosa pine needle, SB: big sagebrush litter, $F$ : rough fescue litter, $M$ : cattle manure.

\section{Discussion}

Substrate condition or seedbed is a major determinant in the regeneration niche for seedlings (Grubb 1977). The 6 seedbed types tested in the present study, including Douglas-fir and ponderosa pine needles, are representative of the forestgrassland ecotone in British Columbia, because conifer trees are common in the grasslands as a result of encroachment. Bare soil surface is generally favorable for conifer seedling emergence because litter accumulations on forest floors restrict seed germination and seedling establishment of conifer trees (Bramble and Goddard 1942, Chrosciewicz 1974, Van Wagner 1983), including Douglas-fir (Caccia and Ballaré 1998) and ponderosa pine (Roe and Squillance 1950, Foiles and Curtis 1965). In the present study, both Douglas-fir needle and big sagebrush litter restricted seedling emergence of Douglas-fir and ponderosa pine compared to mineral soil, but fescue litter and dry cattle manure fragment actually enhanced the emergence of the 2 species. Interestingly, ponderosa pine needles did not restrict seedling emergence of its own or Douglas-fir, possibly because the water availability in our experiment was less limited than in other field studies (Roe and Squillance 1950, Foiles and Curtis 1965).

The effect of litter on seed germination and seedling emergence depends on litter type and species studied; both the physical structure and chemical composition of litter may contribute to differences in seedling emergence observed in the field. Allelopathy has been reported in a wide range of species and the effect was species specific (Grant 1964, Ballester et al. 1979, Kil and Yun 1992). The water extracts of the 6 types of seedbed materials as well as of soils beneath them had no effect on seed germination of ponderosa pine and only a marginal effect on Douglas-fir. The water extract of big sagebrush litter, but not of Douglas-fir needle as previously reported (Daniel and Schmidt 1972), reduced seed germination in Douglas-fir. It is possible that allelopathy, even if it exists in some of the materials studied, could have been reduced during decomposition, since fresh needles or litter were mostly absent on the soil surface when samples were collected in the spring. Nevertheless, structural characteristics of these materials may provide a better explanation of the observed differences among seedbeds.

The effect of structural characteristics of seedbed materials on seed germination and seedling emergence has not received as much attention as allelopathy, possibly due to the difficulty of quantitative comparison among seedbeds. In general, litter materials buffer soil temperatures and help conserve soil moisture (Sydes and Grime 1981, Fowler 1986, Williams et al. 1990). On the other hand, seeds can be entrapped between layers of litter (Burbidge 1945), preventing germination by reducing the contact between seeds and surrounding materials. Even for the same type of litter, horizontal or vertical arrangement pro- duced a different architecture, modifying temperatures under the litter layer (Bristow 1988). Mineral soil and manure fragments had the highest bulk density and relative volume among the 6 types of materials in our study, providing maximum contact with seeds and subsequently optimal water supply for seed germination. On the other hand, ponderosa pine needle and fescue litter were characterized by low bulk density and low relative volume. Therefore, seeds are not likely trapped in their loose structure, but fall through, contacting mineral soil. Douglasfir needle and big sagebrush litter had moderate bulk density and relative volume and seeds are more likely to be trapped within these materials, resulting in low seedling emergence. The 2 factors, namely structural and chemical characteristics, may interactively affect seed germination as reported in the effect of oak litter on seedling emergence of table mountain pine (Pinus pungens Lam.) (Williams et al. 1990).

The effect of structural characteristics of seedbeds is related to moisture availability, which is highly variable in the field and may result in different results from controlled experiments such as the current study. Regardless of seedbed types, over $50 \%$ of seedlings of Douglas-fir and ponderosa pine emerged in the first 4 weeks (data not shown). Seedlings emerging early in the season have survival advantage (Miller 1987, Streng et al. 1989). Grasslands of British Columbia are characterized by low annual precipitation and extremely dry summers (Spilsbury and Tisdale 1944, Tisdale and McLean 1957) and conifer seedling establishment usually occurrs when moisture conditions were close to or above the long-term average (Arno and Gruell 1983, 1986). Successful encroachment of these 2 tree species may therefore depend on the ability of seeds to germinate early in the season when soil moisture conditions are favorable and on seedbeds that can provide sufficient moisture.

In conclusion, seedbeds in grasslands of British Columbia, such as mineral soil, fescue litter and cattle manure fragment, favor seed germination and seedling establishment of Douglas-fir and ponderosa pine compared to those on forest floors, such as Douglas-fir needle. Differences among seedbeds are most likely due to their structural, but not chemical characteristics. Fire suppression, grazing and tree logging will modify the soil surface, and other factors such as weather conditions and competition will interactively influence seedling establishment of the 2 
species. Field studies are therefore necessary for isolating factors causing tree encroachment for specific areas.

\section{Literature Cited}

Arno, S.F. and G.E. Gruell. 1983. Fire history at the forest-grassland ecotone in southwestern Montana. J. Range Manage. 36:332-336.

Arno, S.F. and G.E. Gruell. 1986. Douglas-fir encroachment into mountain grasslands in southwestern Montana. J. Range Manage. 39:272-276.

Ballester, A., A.M. Vietez, and E. Vietez. 1979. The allelopathic potential of Erica aus tralis L. and E. arborea. Bot. Gazette 140:433-436.

Bramble, W.C. and M.K. Goddard. 1942. Effect of animal coaction and seedbed condition on regeneration of pitch pine in the barrens of central Pennsylvania. Ecol. 23:330-335.

Bristow, K.L. 1988. The role of mulch and its architecture in modifying soil temperature. Australian J. Soil Res. 26:269-280.

Burbidge, N.T. 1945. Germination studies of Australian Chenopodiaceae with special reference to the conditions necessary for germination. I. Atriplex vesicaria $\mathrm{H}$. Trans. Royal Soc. of South Australia 69:73-85.

Burkhardt, J.W. and E.W. Tisdale. 1976. Causes of juniper invasion in south-western Idaho. Ecol. 57:472-484.

Caccia, F.D. and C.L. Ballaré. 1998. Effects of tree cover, understory vegetation, and litter on regeneration of Douglas-fir (Pseudotsuga menziesii) in southwestern Argentina. Can. J. Forest Res. 28:638-692.

Chrosciewicz, Z. 1974. Evaluation of fire-produced seedbeds for jack pine regeneration in central Ontario. Can. J. Forest Res. 4:455-457.

Daniel, T.W. and J. Schmidt. 1972. Lethal and nonlethal effects of the organic horizons of the forested soils on the germination of seeds from several associated conifer species on the Rocky Mountains. Can. J. Forest Res. 2:179-184.

Evetts, L.L. and O.C. Burnside. 1972. Germination and seedling development of common milkweed and other species. Weed Sci. 20:371-378.

Foiles, M.W. and J.D. Curtis. 1965. Natural regeneration of ponderosa pine on scarified group cuttings in central Idaho. J. Forest. 63:530-535.

Fowler, N.L. 1986. Microsite requirements for germination and establishment of three grass species. Amer. Midland Natur. 115:131-145.

Grant, E.A. 1964. Influence of plant extracts on germination and growth of eight forage species. J. Brit. Grassl. Soc. 19:191-197.

Grubb, P.J. 1977. The maintenance of speciesrichness in plant communities: The importance of the regeneration niche. Biol. Rev. $52: 107-145$.
Gruell, G.E. 1983. Fire and vegetation trends in the Northern Rockies: Interpretations from 1871-1982 photos. USDA Forest Serv. Gen. Tech. Rep. INT-158. Ogden, Ut.

Hill, J.D., C.D. Canham, and D.M. Wood. 1995. Patterns and causes of resistance to tree invasion in rights of way. Ecol. Appl. 5:459-470.

Kil, B.S. and K.W. Yun. 1992. Allelopathic effects of water extracts of Artemisia prin ceps var. orientalis on selected plant species. J. Chem. Ecol. 18:39-51.

MacDonald, I.A.W. and C. Wissel. 1991. Determining optimal clearing treatments for the alien invasive shrub Acacia saligina in the Southwestern Cape, South-Africa. Agr. Ecosystems and Environ. 39:169-186.

Mast, J.N., T.T. Veblen, and Y.B. Linhart. 1998. Disturbance and climatic influences on age structure of ponderosa pine at the pinegrassland ecotone, Colorado Front Range. J. Biogeography 25:743-755.

McLaren, B.E. and R.A. Janke. 1996. Seedbed and canopy cover effects on balsam fir seedling establishment in Isle Royale National Park. Can. J. Forest Res. 26:782-793.

Miller, T.E. 1987. Effects of emergence time on survival and growth in an early old-field plant community. Oecologia 72:272-278.

Parminter, J.V. 1978. Forest encroachment upon grassland range in the Chilcotin region of British Columbia. M.Sc. Thesis, Univ. of British Columbia. Vancouver, BC.

Richardson, D.M. and W.J. Bond. 1991. Determinants of plant distribution: Evidence from pine invasion. Amer. Natur. 173:639-668.

Roe, A.L. and A.E. Squillance. 1950. Can we induce prompt regeneration in selective-cut ponderosa pine stands? USDA For. Serv., North Rocky Mountain Forest and Range Exp. Sta, Res. Note 81. Missoula, Mont.

Ross, T.J. 1997. Forest ingrowth and forest encroachment on Bald Mountain and Becher Prairie between 1962 and 1993/95. Prepared for: BC Ministry of Agr., Cariboo/Chilcotin Grazing Enhancement Fund. Ross Range and Reclamation Services, Cranbrook, BC.

Snedecor, G.W. and W.C. Cochran. 1980. Statistical methods ( $7^{\text {th }}$ ed.). Iowa State Univ. Press. Ames, Iowa.

Spilsbury, R.H. and E.W. Tisdale. 1944. Soilplant relationships and vertical zonation in the southern interior of British Columbia. Sci. Agr. 24:395-436.

Strang, R.M. and J.V. Parminter. 1980. Conifer encroachment on the Chilcotin grasslands of British Columbia. Forest. Chronicle 56:13-18.

Streng, D.R., J.S. Glitzenstein, and P.A. Harcombe. 1989. Woody seedling dynamics in an East Texas floodplain forest. Ecol. Monogr. 59:177-204.

Sydes, C. and J.P. Grime. 1981. Effects of tree leaf litter on herbaceous vegetation in decidous woodland. II. An experimental investigation. J. Ecol. 69:249-262.

Tisdale, E.W. 1950. Grazing of forest lands in interior British Columbia. J. Forest. 48:856-860.
Tisdale E.W. and A. McLean. 1957. The Douglas fir zone of southern British Columbia. Ecol. Monogr. 27:247-266.

Van Wagner, C.E. 1983. Fire behaviour in northern conifer forests and shrublands, $\mathrm{p}$. 65-80. In: R.W.Wein and D.A. MacLean (eds.), The role of fire in northern circumpolar ecosystems. Wiley, New York, N.Y.

Whitford, H.N. and R.D. Craig. 1918. Forest of British Columbia. Canada Comm. on Forests, Ottawa, ON.

Williams, C.E., M.V. Lipscomb, W.C. Johnson, and E.T. Nilsen. 1990. Influence of leaf litter and soil moisture regime on early establishment of Pinus pungens. Amer. Midland Natur. 124:142-152. 